\title{
EXPERIMENTALWORKS
}

UDC 573.6.083.3+573.6.086.8

doi: https://doi.org/10.15407/ubj89.01.022

\section{CHARACTERISTICS OF ENZYME-LINKED IMMUNOSORBENT ASSAY FOR DETECTION OF IGG ANTIBODIES SPECIFIC TO Chlamydia trachomatis HEAT SHOCK PROTEIN (HSP-60)}

\author{
O. YU. GALKIN, A. B. BESARAB, T. N. LUTSENKO
}

National Technical University of Ukraine “Igor Sikorsky Kyiv Polytechnic Institute”; e-mail:alexbio@mail.ua

The goal of this work was to study sensitivity and specificity of the developed ELISA set for the identification of IgG antibodies against Chlamydia trachomatis HSP-60 (using biotinylated tyramine-based signal amplification system). The study was conducted using a panel of characterized sera, as well as two reference ELISA sets of similar purpose. According to the results of ELISA informative value parameters, the ELISA we have developed showed the highest specificity and sensitivity parameters (no false negative or false positive results were registered). In 4 out of 15 intralaboratory panel serum samples initially identified as negative, anti-HSP-60 IgG-antibodies test result in reference ELISA sets upon dilution changed from negative to positive. The nature of titration curves of false negative sera and commercial monoclonal antibodies A57-B9 against C. trachomatis HSP-60 after incubation for $24 \mathrm{~h}$ was indicative of the presence of anti-idiotypic antibodies in these samples. Upon sera dilution, idiotypic-anti-idiotypic complexes dissociated, which caused the change of test result. High informative value of the developed ELISA set for identification of IgG antibodies against C. trachomatis HSP-60 has been proven. Anti-idiotypic antibodies possessing C. trachomatis anti-HSP-60 activity and being one of the causes of false negative results of the relevant ELISA-based tests have been identified in blood sera of individuals infected with chlamydial genitourinary infection agents.

Key words: enzyme-linked immunosorbent assay, Chlamydia trachomatis, heat shock protein, anti-idiotypic antibodies, sensitivity, specificity.

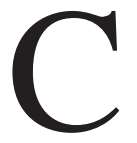
hlamydial genitourinary infection (GUI) is one of the most common sexually transmitted infections. According to World Health Organization, Chlamydia trachomatis infects about 90 million people each year by sexual transmission. In Ukraine, the rate of chlamydial GUI is 80 cases per 100,000 population. Nearly $16 \%$ of pregnant women are infected with $C$. trachomatis. About $50-60 \%$ of tubular infertility cases are caused by chlamydial infection. A quarter of all ophthalmic and respiratory diseases in newborn and younger children are associated with chlamydial infection $[1,2]$.

Effective diagnosis is one of important components of chlamydial GUI control, which can be realized through both direct (detection of antigens, nucleic acids, pathogenic agent microscopic examination and cultivation) and indirect (specific antibodies detection) techniques. One of the commonly used methods in diagnostics is enzyme-linked immunosorbent assay (ELISA) that allows differential diagnosis - determination of disease stage and course, which is especially important in chronic conditions. For that purpose blood serum (plasma) and human biological fluids are tested for the presence of $\operatorname{IgM}, \operatorname{IgA}$ and $\mathrm{IgG}$ classes of specific antibodies to pathogen's antigens [2, 3].

Prolonged persistency of $C$. trachomatis increases the expression of heat shock protein with molecular mass $60 \mathrm{kDa}$ (HSP-60), which is highly

(C) 2017 Galkin O. Yu. et al. This is an open-access article distributed under the terms of the Creative Commons Attribution License, which permits unrestricted use, distribution, and reproduction in any medium, provided the original author and source are credited. 
homologous with respective natural protein in human cells. Its production results in molecular mimicry phenomena, which in turn triggers autoimmune processes. Increased level of immune system stimulation by heat shock protein that occurs in case of reinfection or persistent infection leads to chronic inflammation and scarring of tissues and may play a role in pathogenesis of endometrial and uterine adnexal lesions. These immunopathological reactions may be the cause of ectopic pregnancy and tubular infertility $[4,5]$. Thus, examination of patients infected with $C$. trachomatis for the presence of IgG antibodies to HSP-60 is essential.

The relevance of the work to improve the sensitivity of ELISA for detection of IgG antibodies to HSP-60 is linked to the fact that HSP-60 is a marker of autoimmune processes (complications of urogenital infections). Such tests are carried out after primary diagnosis, including the use of molecular genetic techniques (e.g. polymerase chain reaction, PCR).

Earlier in the study, we obtained biologic components for development of ELISA set in order to carry out qualitative (semiquantitative) detection of IgG antibodies to HSP-60 C. trachomatis $[4,6]$.

This study aimed at evaluation of diagnostic characteristics of enzyme-linked immunosorbent assay for detection of IgG antibodies to HSP-60 C. trachomatis.

\section{Materials and Methods}

Blood sera. Blood sera of persons infected with C. trachomatis (diagnosis confirmed by PCR) were used in the study.

Immunoenzymatic kits. Commercial ELISA kits developed for detection of IgG antibodies to HSP-60 C. trachomatis: \#1 (Germany) and \#2 (Russia) were also used.

Indirect enzyme-linked immunosorbent assay. Recombinant HSP-60 C. trachomatis adsorption was performed in $0.05 \mathrm{M}$ carbonate-bicarbonate buffer solution ( $\mathrm{pH} 9.6$ ) for $12 \mathrm{~h}$ at $4{ }^{\circ} \mathrm{C}$ at concentration of $4 \mu \mathrm{g} / \mathrm{ml}$. Free areas on surface of plates' wells were filled by bovine serum albumin solution.

The wells were injected with $100 \mu$ of studied human blood sera and incubated at $37^{\circ} \mathrm{C}$ for $1 \mathrm{~h}$, then washed out three times with $0.02 \mathrm{M}$ phosphatebuffered saline with Tween-20, pH 7.2-7.4 (PBST). To detect specific antigens, there was used conjugate of monoclonal antibodies to human IgG with horseradish peroxidase incubated at $37^{\circ} \mathrm{C}$ for $30 \mathrm{~min}$. After incubation the plate was washed out with PBST and injected with chromogenic substrate solution (3,3',5,5'-tetramethylbenzidine, $0.003 \% \mathrm{H}_{2} \mathrm{O}_{2}, 0.15 \mathrm{M}$ citrate bufferred solution, $\mathrm{pH}$ 5.0). Following the enzymatic reaction stop, optical density (OD) of solution was measured at wavelength $450 \mathrm{~nm}$.

Indirect enzyme-linked immunosorbent assay with biotinylated tyramine reagent was carried out using the same procedure, however after sera incubation the wells were first injected with biotinylated tyramine reagent ELAST ELISA Amplification System (PerkinElmer, USA) according to instruction manual.

\section{Results and Discussion}

Due to their absence in the market of control materials, it was impossible to use standardized serum sets for the evaluation of ELISA diagnostic characteristics during detection of antibodies to HSP-60 C. trachomatis. In this case, the only available methodological approach is formation of our own intralaboratory (or in-process) serum sets and performance of comparative analysis using similar purpose diagnostic ELISA kits manufactured by various companies.

To produce our own serum set negative to specific antibodies to $C$. trachomatis, obtained sera were tested for the presence of specific IgG antibodies to pathogenic HSP-60 using ELISA kits \#1 and \#2. The pool of negative sera included those exhibiting positive results during testing for antibodies to other antigens of pathogen (major outer membrane protein, Pgp3). This technique allowed formation of intralaboratory set consisting of 15 positive and 20 negative sera.

In order to substantiate the modification of ELISA for detection of IgG-antibodies specific for HSP-60 C. trachomatis it makes sense to address the following literature data.

First, various authors reported on possible divergence of results obtained in different tests (serum, molecular genetic, culture-based tests) during diagnosis of chlamydial genitourinary infection [7-11]. These data suggest various informative values of the said clinical laboratory examination techniques. At the same time, there is no consensus on the nature of such discrepancies. For instance, negative results of serum tests in some patients appear quite strange in the presence of positive results for detected pathogen's nucleic acids in urogenital smear by PCR. The most common explanation of this fact relates to low test sensitivity or low level of humoral immune response to pathogen. 
Secondly, currently available scientific data on heat shock proteins interaction with immune system make it possible to content that HSP is the element of macro organism immune regulatory network similarly to idiotypic and anti-idiotypic system. This can be proven by following facts: their availability in both eukaryotic and prokaryotic organisms; presence of highly conserved sequences in the structure of HSP, which are also immunodominant; high immunologic activity of HSP. The HSP-dependent system (network) of inflammation and autoimmunity stimulation and regulation includes, at any rate, following elements: HSP as polyreactive antigens; natural autoantibodies and anti-idiotypic antibodies; proteins of macro organism as such released from the cells due to various reasons; foreign proteins (including HSP of microorganisms); antigen-presenting cells that can be activated by HSP; effector and regulatory T-lymphocytes interacting with HSP [12-15].

Thirdly, there are numerous reports in modern scientific literature on idiotypic and anti-idiotypic interactions in blood serum of mammals and humans, including rather successful, in our opinion, attempts of mathematic modelling of this interaction, similarly to ligand-receptor interaction [16-18]. Original approach to detection of idiotypic and anti-idiotypic interactions in polyclonal sera involves synchronic changes in receptor and ligand concentrations (primary and anti-idiotypic antibodies) in the studied system (serum) [17, 18]. This approach allows us to determine theoretically the concentration of antigenantibody complex (ci) depending on the dilution ratio of the serum (1)

$$
c_{i}=\frac{d_{i} l K+d_{i} r_{0} K+d_{i}^{2}-\sqrt{\left(d_{i} l K+d_{i} r_{0} K+d_{i}^{2}\right)^{2}-4 d_{i}^{2} l_{0} K^{2}}}{2 d_{i}^{2} K},
$$

where $d_{\mathrm{i}}$ - serum dilution factor, $l$ - initial ligand (antigen) concentration, $r_{0}$ - initial concentration of bivalent receptor (antibody), $K$ - constant of antigenantibody reaction equilibrium (invariable of antibody affinity) [18].

It is also possible to calculate within this theory [18] following probabilities: 1) both centers of any receptor are bound to ligand $\left(f_{1}\right)$; 2 ) both binding centers of any bivalent receptor are free $\left(f_{2}\right)$; 3 ) when the equilibrium is reached one of the binding centers of receptor will become free while the other - bound to ligand $\left(f_{3}\right)$. The said probabilities are also dependent on the dilution ratio of sera di (2-4):

$$
\begin{aligned}
& f_{1}=\frac{c_{i}^{2} d_{i}^{2}}{r_{0}^{2}}, \\
& f_{2}=\frac{\left(r_{0}-c_{i} d_{i}\right)^{2}}{r_{0}^{2}}, \\
& f_{3}=1-f_{1}-f_{2}=\frac{2 c_{i} d_{i}\left(r_{0}-c_{i} d_{i}\right)}{r_{0}^{2}} .
\end{aligned}
$$

Graphic presentation of free antibodies concentrations dependence in their mixture with antigen on dilution ratio of the mixture (serum) is given in Fig. 1.

Based on the above, further investigations with regard to the development of ELISA for detection of IgG class antibodies specific for HSP-60 C. trachomatis were performed in two directions: firstly, development of classic indirect ELISA for detection of IgG-antibodies (our reference designation: ELISA-HSP-IgG); secondly, development of indirect ELISA using biotinylated tyramine reagent (our reference designation: ELISA-HSP-IgG-TB), which efficiency we have already proved [19]. In the latter case, analyte-mediated enzyme activating system of signal amplification allows performing studies of diluted sera, which, in turn, creates opportunities for

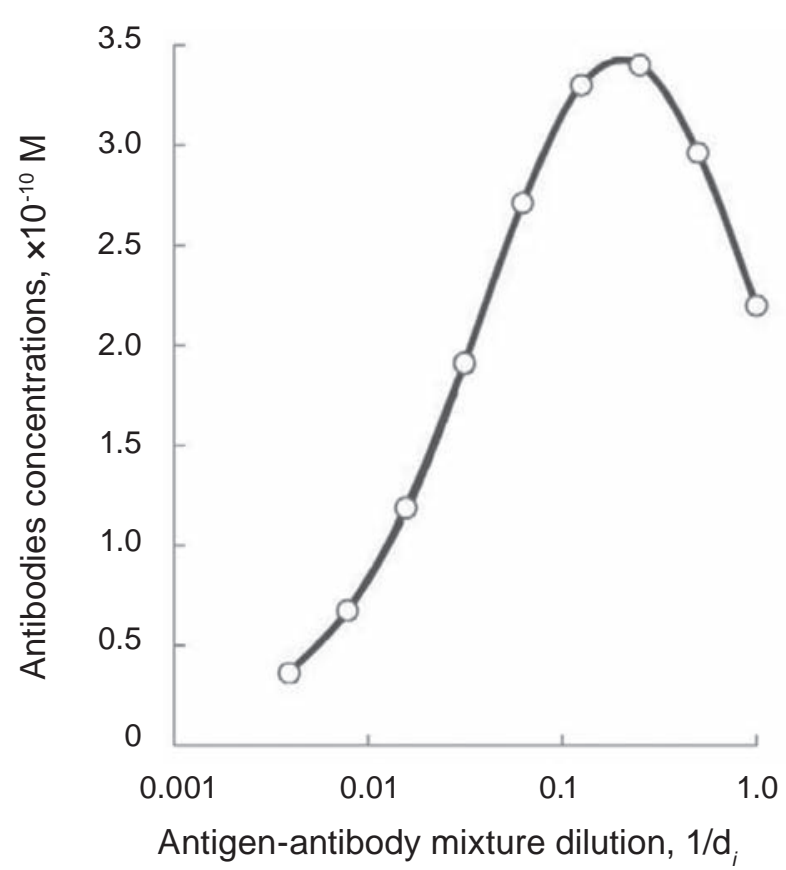

Fig. 1. Theoretical dependence of free bivalent antibodies concentrations in their mixture with antigen on the dilution ratio of such mixture $d_{i}$-fold [18] 
examination on the presence of anti-idiotypic antibodies in studied sera.

The first stage of the study included comparative characteristic of the developed classical indirect ELISA (ELISA-HSP-IgG) with ELISA-kits by various manufacturers. Obtained results (Tables 1-2) show that informative value of our developed ELISA is not inferior to commercial equivalents and in some ways even superior to them.

Following stage of the study comprised testing of diluted (1:4 ...1:64) negative sera of intralaboratory serum set in developed ELISA using biotinylated tyramine reagent (ELISA-HSP-IgG-TB). It should be noted that testing of diluted sera was carried out following their incubation in wells of ELISA plates at $4{ }^{\circ} \mathrm{C}$ for $24 \mathrm{~h}$. For all the samples, except 4 which were initially identified as negative, negative results were obtained during titration of sera of intralaboratory serum set. It is worth noting that all these sera were positive with regard to IgG antibodies to MOMP/Pgp3 C. trachomatis. The testing results of false-negative samples of intralaboratory serum set are given in Table 3. Titration curves of these sera compared to titration of monoclonal antibody A57B9 (Thermoscientific, USA), specific for HSP-60 C. trachomatis, are given in Fig. 2.

The results of the study show that sera of intralaboratory serum set No.22, 26, 27 and 31 contain certain factors able to block the anti-HSP-60 antibodies when undiluted. The titration curves compared to MABs specific for HSP-60 of chlamydial genitourinary infection allows concluding that antiidiotypic antibodies are likely to be present in these sera, which constitute the factor blocking the activity of anti-HSP-60 antibodies.

These data provide an answer, at least one of possible answers, to the question concerning falsenegative results of ELISA testing on the presence of antibodies specific for $C$. trachomatis in patients with confirmed diagnosis by PCR. It should be noted that obtained results point to the need to use less convenient in terms of ergonomics schemes of ELISA testing for respective diagnostic kits, which includes prolonged samples incubation and their titration. This task can obviously be completed only using ELISA kits build on effective signal amplification systems.

As was mentioned earlier, existing literature data [7-11] are indicative of rather frequent variations in results of different laboratory tests of chlamydial genitourinary infection, in particular, molecular- genetic, serological, and microbiological ones. This situation is rather unfavorable from the viewpoint of practical medicine and requires elevation of informative value (reliability) of laboratory methods for diagnostics of this infection. False positive and false negative results of serological tests may be obtained due to not only bioanalytical characteristics (limitations) of the test method itself (related with properties of biological reagents and "structure" of ELISA itself), but also to the presence of substances in the test material which bias the test results in various ways. Thus, e.g. influence of antigen mimicry on informative value of HIV infection serological diagnostics has been described [20].

In view of several particulars of formation of B-cell response to heat shock proteins [12-15], as well as reports on potential effects of anti-idiotypic serum antibodies on the nature of immunochemical reactions (e.g. so-called prozone effect in tests based on agglutination or precipitation reaction) [1618]; additionally, development of indirect ELISA for identification of anti-HSP-60 IgG-antibodies using biotinylated tyramine reagent was performed. This modification allowed carrying out identification of specific antibodies in dilute serum samples $(1: 4 \div 1: 64)$, and, respectively, measuring the content of anti-idiotypic antibodies in them. In 4 out of 15 intralaboratory panel (ILP) serum samples initially identified as negative, anti-HSP-60 IgG-antibodies test result upon dilution changed from negative to positive. The nature of titration curves of false negative ILP sera and commercial MAB A57-B9 against C. trachomatis HSP-60 after incubation for $24 \mathrm{~h}$ was indicative of the presence of anti-idiotypic antibodies in these samples. Upon sera dilution, idiotypicanti-idiotypic complexes dissociated that caused the change of test result.

The results of these studies, at first, are indicative of the cause (at least one of the causes) of false negative results of chlamydial genitourinary infection serological tests, and, at second, are the prerequisites for the development of new strategy of complex examination of patients for the presence of $C$. trachomatis infection. Obviously, in case of positive PCR test result and negative serological test result of chlamydial genitourinary infection, additional testing of such samples in a series of dilutions is expedient. To solve this problem, highly sensitive ELISA sets are to be used, for example, employing biotinylated tyramine-based signal amplification system. In our opinion, the issue of clinical rele- 
Ta b le 1. Study results on sensitivity and specificity of various ELISA assays for detection of IgG antibodies to C. trachomatis HSP-60 using intralaboratory serum set

\begin{tabular}{|c|c|c|c|c|c|c|}
\hline \multirow{3}{*}{$\begin{array}{l}\text { No. of sample } \\
\text { intralaboratory } \\
\text { serum set }\end{array}$} & \multicolumn{6}{|c|}{ Various ELISA kits } \\
\hline & \multicolumn{2}{|c|}{ ELISA-HSP-IgG } & \multicolumn{2}{|c|}{$\# 1$} & \multicolumn{2}{|r|}{$\# 2$} \\
\hline & OD & Positivity index & OD & Positivity index & OD & Positivity index \\
\hline \multicolumn{7}{|c|}{ Positive samples } \\
\hline 1 & $0.358 *$ & 1.80 & 0.479 & 1.11 & 0.577 & 1.41 \\
\hline 2 & 0.563 & 2.83 & 0.491 & 1.14 & 0.541 & 1.32 \\
\hline 3 & 0.525 & 2.64 & 0.478 & 1.11 & 0.461 & 1.12 \\
\hline 4 & 0.954 & 4.79 & 0.494 & 1.15 & 0.562 & 1.37 \\
\hline 5 & 1.234 & 6.19 & 1.411 & 3.28 & 1.841 & 4.49 \\
\hline 6 & 2.029 & 10.18 & 1.988 & 4.62 & 1.749 & 4.27 \\
\hline 7 & 0.856 & 4.30 & 0.922 & 2.14 & 1.110 & 2.71 \\
\hline 8 & 0.696 & 3.49 & 0.501 & 1.17 & 0.580 & 1.41 \\
\hline 9 & 0.774 & 3.88 & 0.804 & 1.87 & 0.591 & 1.44 \\
\hline 10 & 0.914 & 4.59 & 0.911 & 2.12 & 1.410 & 3.44 \\
\hline 11 & 1.045 & 5.25 & 1.100 & 2.56 & 2.810 & 6.85 \\
\hline 12 & 1.667 & 8.37 & 1.209 & 2.81 & 1.840 & 4.49 \\
\hline 13 & 2.147 & 10.78 & 1.893 & 4.40 & 2.410 & 5.88 \\
\hline 14 & 1.520 & 7.63 & 1.440 & 3.35 & 2.550 & 6.22 \\
\hline 15 & 1.509 & 7.57 & 1.169 & 2.72 & 1.070 & 2.61 \\
\hline \multicolumn{7}{|c|}{ Negative samples } \\
\hline 16 & 0.049 & 0.25 & 0.108 & 0.25 & 0.158 & 0.39 \\
\hline 17 & 0.031 & 0.16 & 0.140 & 0.33 & 0.250 & 0.61 \\
\hline 18 & 0.047 & 0.24 & 0.098 & 0.23 & 0.142 & 0.35 \\
\hline 19 & 0.108 & 0.54 & 0.144 & 0.33 & 0.199 & 0.49 \\
\hline 20 & 0.048 & 0.24 & 0.107 & 0.25 & 0.085 & 0.21 \\
\hline 21 & 0.098 & 0.49 & 0.054 & 0.13 & 0.078 & 0.19 \\
\hline 22 & 0.152 & 0.76 & 0.177 & 0.41 & 0.245 & 0.60 \\
\hline 23 & 0.057 & 0.29 & 0.074 & 0.17 & 0.096 & 0.23 \\
\hline 24 & 0.032 & 0.16 & 0.065 & 0.15 & 0.071 & 0.17 \\
\hline 25 & 0.033 & 0.17 & 0.044 & 0.10 & 0.074 & 0.18 \\
\hline 26 & 0.095 & 0.48 & 0.195 & 0.45 & 0.149 & 0.36 \\
\hline 27 & 0.136 & 0.68 & 0.203 & 0.47 & 0.201 & 0.49 \\
\hline 28 & 0.085 & 0.43 & 0.054 & 0.13 & 0.188 & 0.46 \\
\hline 29 & 0.073 & 0.37 & 0.098 & 0.23 & 0.103 & 0.25 \\
\hline 30 & 0.062 & 0.31 & 0.058 & 0.13 & 0.111 & 0.27 \\
\hline 31 & 0.165 & 0.83 & 0.274 & 0.64 & 0.274 & 0.67 \\
\hline 32 & 0.029 & 0.15 & 0.068 & 0.16 & 0.147 & 0.36 \\
\hline 33 & 0.103 & 0.52 & 0.099 & 0.23 & 0.095 & 0.23 \\
\hline 34 & 0.042 & 0.21 & 0.159 & 0.37 & 0.104 & 0.25 \\
\hline 35 & 0.050 & 0.25 & 0.178 & 0.41 & 0.094 & 0.23 \\
\hline
\end{tabular}


Ta b le 2. Comparative analysis of various ELISA for detection of IgG-antibodies to C. trachomatis HSP-60

\begin{tabular}{l|c|c|c}
\hline \multirow{2}{*}{\multicolumn{1}{c|}{ Assay specifications }} & \multicolumn{3}{|c}{ Various ELISA kits } \\
\cline { 2 - 4 } & $\# 1$ & $\# 2$ & ELISA-HSP-IgG \\
\hline Mean OD value for negative sera & 0.120 & 0.143 & 0.075 \\
Mean OD value for positive sera & 1.019 & 1.340 & 1.119 \\
Threshold & 0.430 & 0.410 & 0.199 \\
Correlation of mean OD values & & & \\
for positive and negative sera & 8.51 & 9.36 & 14.98 \\
\hline
\end{tabular}

Table 3. Titration results of false-negative samples of intralaboratory serum set on the presence of IgGantibodies to C. trachomatis HSP-60

\begin{tabular}{c|c|c|c|c|c}
\hline \multirow{2}{*}{$\begin{array}{c}\text { No. of sample } \\
\text { intralaboratory }\end{array}$} & \multicolumn{5}{|c}{ Optical density of various samples dilutions } \\
\cline { 2 - 6 } serum set & $1: 4$ & $1: 8$ & $1: 16$ & $1: 32$ & $1: 64$ \\
\hline $\mathbf{2 2}$ & 0.032 & 0.035 & 0.984 & 0.054 & 0.034 \\
$\mathbf{2 6}$ & 0.041 & 0.041 & 0.817 & 0.229 & 0.084 \\
$\mathbf{2 7}$ & 0.034 & 0.179 & 0.408 & 0.152 & 0.047 \\
$\mathbf{3 1}$ & 0.084 & 0.047 & 0.084 & 0.234 & 0.043 \\
\hline
\end{tabular}

Note. Specified are arithmetic mean values for OD for each sample in three repetitions; $P<0.05$

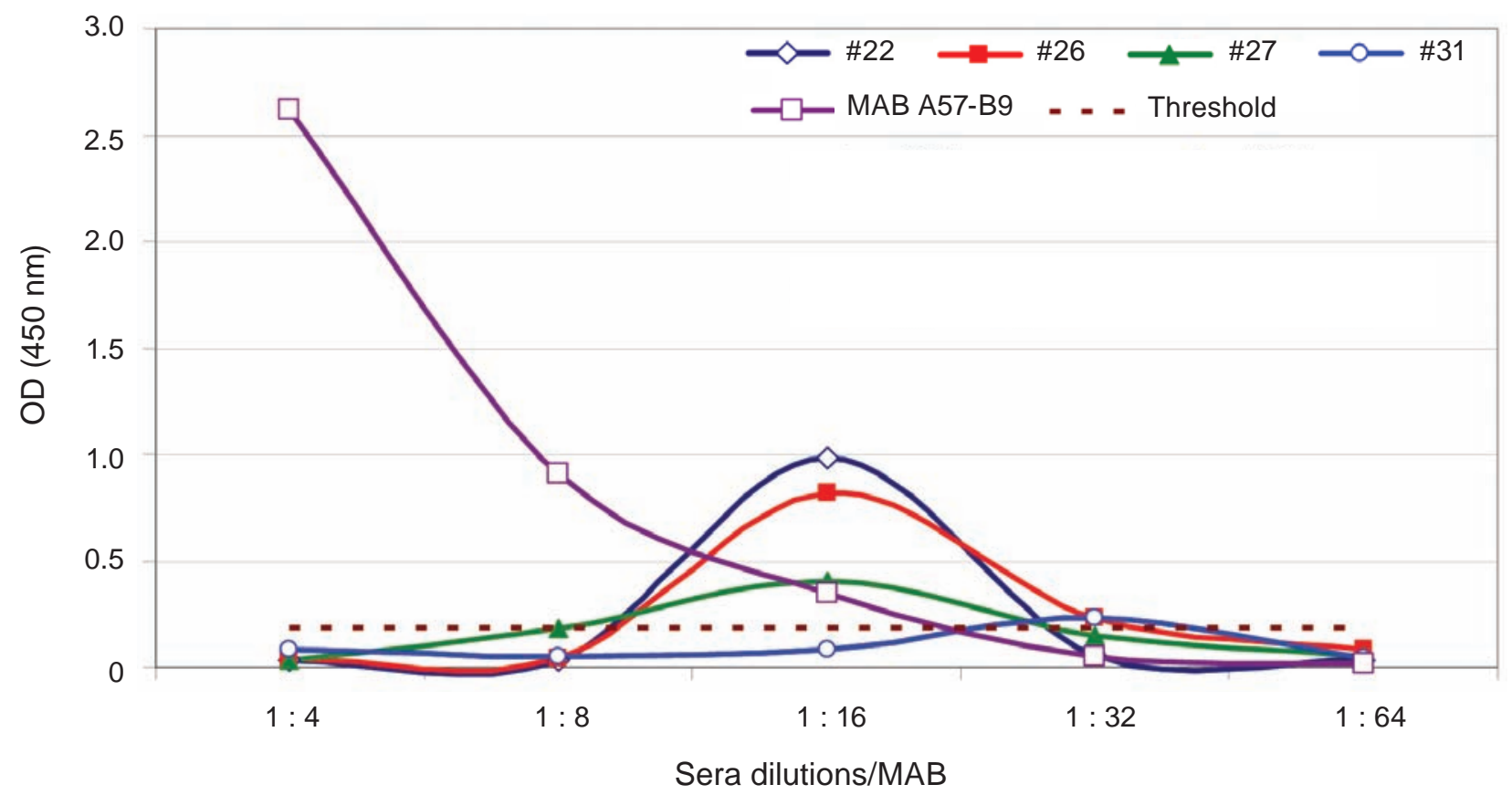

Fig. 2. Titration curves of false-negative sera for intralaboratory serum set and MAT A57-B9 to HSP-60 C. trachomatis following incubation at $4{ }^{\circ} \mathrm{C}$ for $24 \mathrm{~h}$ (effect on the ability of antibodies to bind to adsorbed antigen on plate) 
vance of the presence of high titer of anti-idiotypic antibodies in individuals infected with chlamydial genitourinary infection agents is interesting from the viewpoint of clinical immunology.

Sensitivity and specificity study has proven high informative value of the developed ELISA set for identification of IgG antibodies against C. trachomatis HSP-60.

Anti-idiotypic antibodies possessing C. trachomatis anti-HSP-60 activity and being one of the causes of false negative results of the relevant ELISA-based tests have been identified in blood sera of individuals infected with chlamydial genitourinary infection agents.

\section{ХАРАКТЕРИСТИКИ ІМУНОЕНЗИМАТИЧНОГО АНАЛІЗУ ДЛЯ ВИЯВЛЕННЯ IGG АНТИТІЛ ДО ПРОТЁ̈НУ ТЕПЛОВОГО ШОКУ (НSР-60) Chlamydia trachomatis}

\section{О. Ю. Галкін, О. Б. Бесараб, Т. М. Луценко}

\author{
Національний технічний університет \\ України «Київський політехнічний \\ інститут імені Ігоря Сікорського»; \\ e-mail: alexbio@mail.ua
}

Метою роботи було дослідження чутливості та специфічності розробленого імуноензиматичного (IE) набору для виявлення антитіл класу IgG до HSP-60 Chlamydia trachomatis (застосовуючи тирамін-біотинову систему ампліфікації сигналу). Дослідження проводили із використанням охарактеризованої панелі сироваток, а також двох референтних IE-наборів аналогічного призначення. Результати вивчення інформативності імуноензиматичного аналізу (IEA) для розробленого нами IEA показали найвищі специфічність та чутливість (не було зафіксовано хибнонегативних та хибнопозитивних результатів). У 4 із 15 зразків сироваток внутрішньолабораторної панелі, що первинно ідентифіковано як негативні, у разі їх розведення результат визначення антиHSP-60 IgG-антитіл у референтних IE-наборах змінювався 3 негативного на позитивний. Характер кривих титрування хибнонегативних сироваток та комерційних моноклональних антитіл А57-B9 до HSP-60 C. trachomatis після інкубації протягом 24 год свідчив про присутність у цих зразках антиідіотипових антитіл. За розведення сироваток ідіотипантиідіотипові комплекси дисоціювали, що й обумовлювало зміну результату тестування. Доведено високу інформативність розробленого IE-набору для виявлення антитіл класу $\operatorname{IgG}$ до HSP-60 C. trachomatis. У сироватках крові осіб, інфікованих збудником урогенітального хламідіозу, виявлено антиідіотипові антитіла, які виявляють анти-HSP-60 C. trachomatis активність та $є$ однією 3 причин хибнонегативних результатів відповідних тестів на основі IEA.

К л ю чо в і с лов в: імуноензиматичний аналіз, Chlamydia trachomatis, протеїн теплового шоку, антиідіотипові антитіла, чутливість, специфічність.

\section{ХАРАКТЕРИСТИКИ ИММУНОЭНЗИМНОГО АНАЛИЗА ДЛЯ ВЫЯВЛЕНИЯ IgG АНТИТЕЛ К ПРОТЕИНУ ТЕПЛОВОГО ШОКА (HSP-60) Chlamydia trachomatis}

$$
\begin{gathered}
\text { A. Ю. Галкин, А. Б. Бесараб, Т. Н. Луцеенко } \\
\text { Национальный технический университет } \\
\text { Украины «Киевский политехнический } \\
\text { институт имени Игоря Сикорского»; } \\
\text { e-mail: alexbio@mail.ua }
\end{gathered}
$$

Целью работы было исследование чувствительности и специфичности разработанного иммуноэнзимного (ИЭ) набора для выявления антител класcа IgG к HSP-60 Chlamydia trachomatis (с использованием тирамин-биотиновой системы амплификации сигнала). Исследования проводили с использованием охарактеризованной панели сывороток, а также двух референтных ИЭ-наборов аналогичного назначения. Результаты изучения информативности иммуноэнзиматического анализа (ИЭА) для разработанного нами ИЭА показали высокую специфичность и чувствительность (не было зафиксировано ложноотрицательных и ложноположительных результатов). В 4 из 15 образцов сывороток внутрилабораторной панели, которые первично были идентифицированы как отрицательные, при их разведении результат определения антиHSP-60 IgG-антител в референтных ИЭ-наборах изменялся с отрицательного на положительный. Характер кривых титрования ложноотрицатель- 
ных сывороток и коммерческих моноклональных антител A57-B9 к HSP-60 C. trachomatis после инкубации в течение 24 часов свидетельствовал о присутствии в данных образцах антиидиотипических антител. При разведении сывороток идиотип-антиидиотипические комплексы диссоциировали, что и обусловливало изменение результата тестирования. Доказана высокая информативность разработанного ИЭ-набора для выявления антител класса $\operatorname{IgG}$ к HSP-60 C. trachomatis. В сыворотках крови лиц, инфицированных возбудителем урогенитального хламидиоза, обнаружены антиидиотипические антитела, обладающие анти-HSP-60 C. trachomatis активностью и являющиеся одной из причин ложноотрицательных результатов соответствующих тестов на основе ИЭА.

К л юч е вы е сл о в а: иммуноэнзимный анализ, Chlamydia trachomatis, протеин теплового шока, антиидиотипические антитела, чувствительность, специфичность.

\section{References}

1. Mavrov GI, Scherbakova YuV, Chinov GP. The treatment of complicated chamydial infection with azithromycin (Sumamed) using in combination with pathogenetic therapy. $U k r J$ Dermatol Venerol Cosmetol. 2010; (3(38)): 123127. (In Russian).

2. Medical microbiology, virology, immunology. Ed. V.P. Shyrobokov. Vinnitsa: Nova knyga, 2011. 951 p. (In Ukrainian).

3. Biotechnological bases of creation of medical devises for serological diagnosis of infectious and non-infectious diseases: Monograph / O.Yu. Galkin, V.P. Shyrobokov, A.A. Grigorenko, O.M. Dugan, T.M. Lutsenko, A.G. Komar; Ed. V.P. Shyrobokov. Kiev: NTUU “KPI”, 2015. 204 p. (In Ukrainian).

4. Galkin OYu, Besarab OB, Gryshyna AS, Dugan OM, Gurzhenko YuM. Biotechnology for obtaining the recombinant heat shock protein (HSP-60) of Chlamydia trachomatis and evaluation of the perspectives of its use in serological diagnostics. Sci Herald Chernivtsi Univ. Biology (Biol System). 2014; 6(2): 130-138.

5. Rakhmatullina MR, Popov DV, Plakhova KI. Current concepts of the epidemiology, clinical picture, diagnostics and therapy of noncomplicated and complicated forms of the urogenital chlamydia infection in men. Vestnik Dermatol Venerol. 2012; 6: 35-41. (In Russian).

6. Galkin OYu, Solovjova VF, Metalnikova NP, Dugan OM, Gorgo YuP. Obtaining of monoclonal antibodies to human IgG suitable for usage in highly sensitive and specific immunoassays. Visnyk Zaporizh Nat Univ. Biol. Sci. 2014; 2: 120-129.

7. Jensen IP, Fogh H, Prag J. Diagnosis of Chlamydia trachomatis infections in a sexually transmitted disease clinic: evaluation of a urine sample tested by enzyme immunoassay and polymerase chain reaction in comparison with a cervical and/or a urethral swab tested by culture and polymerase chain reaction. Clin Microbiol Infect. 2003; 9(3): 194-201.

8. Bébéar C, de Barbeyrac B. Genital Chlamydia trachomatis infections. Clin Microbiol Infect. 2009; 15(1): 4-10.

9. Baud D, Zufferey J, Hohlfeld P, Greub G. Performance of an automated multiplex immunofluorescence assay for detection of Chlamydia trachomatis immunoglobulin G. Diagn Microbiol Infect Dis. 2014; 78(3): 217-219.

10. Sulaiman S, Chong PP, Mokhtarudin R, Lye MS, Wan Hassan WH. Comparison of nested and ELISA based polymerase chain reaction assays for detecting Chlamydia trachomatis in pregnant women with preterm complications. Trop Biomed. 2014; 31(1): 6-45.

11. Isakov V.A., Kulyashova L.B., Berezina L.A., Svarval A.V. Laboratory diagnosis of urogenital chlamydiosis. 2. Modern methods of diagnostics of chlamydia infections: analytical review. Terra Medica Labor Diagn. 2013; 1: 13-21. (In Russian).

12. Galkin OYu, Kazmirchuk VYe, Metal'nikova NP. Heat Shock Proteins: Role in Formation of Immune Response. Res Bull NTUU “KPI”. 2014; 3: 12-20. (In Ukrainian).

13. Giuliano JS Jr, Lahni PM, Wong HR, Wheeler DS. Pediatric Sepsis - Part V: Extracellular Heat Shock Proteins: Alarmins for the Host Immune System. Open Inflamm J. 2011; 4: 4960.

14. Pockley AG. Heat shock proteins as regulators of the immune response. Lancet. 2003; 362(9382): 469-476.

15. Habich C, Kempe K, Gomez FJ, Lillicrap M, Gaston H, van der Zee R, Kolb H, Burkart V. Heat shock protein 60: identification of specific 
epitopes for binding to primary macrophages. FEBS Lett. 2006; 580(1): 115-120.

16. Behn U. Idiotypic networks: toward a renaissance? Immunol Rev. 2007; 216: 142-152.

17. Bobrovnik SA. Ligand-receptor interactions: a new method for determining the binding parameters. J Biochem Biophys Methods. 2003; 55(1):7 1-86.

18. Bobrovnik SA. Idiotype-antiidiotypic interaction of antibodies in the bloodstream. Ukr Biochem J. 2014; 86(2): 89-100. (In Russian).
19. Stefatić D, Riederer M, Balić M, Dandachi N, Stanzer S, Janesch B, Resel M, Ler D, Samonigg H, Bauernhofer T. Optimization of diagnostic ELISA-based tests for the detection of auto-antibodies against tumor antigens in human serum. Bosn J Basic Med Sci. 2008; 8(3): 245-250.

20. Ivanskaya NV. Significance of antigenic mimicry when determining antibodies to human immunodeficiency virus in sera of patients with tuberculosis. Lab Diagn. 2011; (1(55)): 39-44.

Received 28.10.2016 